\title{
POPULASI DAN BIOMASSA CACING TANAH PADA BERBAGAI VEGETASI DI SETIAP KEMIRINGAN LERENG SERTA KORELASINYA TERHADAP KESUBURAN TANAH DI LABORATORIUM LAPANG TERPADU FAKULTAS PERTANIAN UNIVERSITAS LAMPUNG
}

\author{
Flora Gamasika, Sri Yusnaini, Ainin Niswati \& Dermiyati \\ Jurusan Agroteknologi Fakultas Pertanian Universitas Lampung \\ Jl. Soemantri Brojonegoro No. 1, Bandar Lampung, Lampung 35145 \\ Email: gamasika@gmail.com
}

\begin{abstract}
ABSTRAK
Laboratorium Lapangan Terpadu Fakultas Pertanian Universitas Lampung merupakan salah satu fasilitas yang disediakan untuk menunjang kegiatan perkuliahan, terdiri atas beberapa unit lahan dengan kemiringan lereng yang berbeda. Di Laboratorium Lapang Terpadu dapat ditemukan berbagai macam vegetasi yaitu sawah, pisang, singkong, kakao, tebu, alang-alang, karet, bambu. Beragamnya vegetasi yang tersebut akan berdampak pada kualitas bahan organik yang dihasilkan dan akan berpengaruh dengan keberagaman biota tanah termasuk cacing tanah. Penelitian ini bertujuan untuk untuk mengetahui pengaruh vegetasi pada kemiringan lereng yang berbeda terhadap populasi cacing tanah serta korelasinya dengan kesuburan tanah di Laboratorium Lapang Terpadu Unila. Penelitian ini dilakukan dengan pengambilan sampel pada 15 titik dengan 3 ulangan pada masingmasing titik. Penentuan titik sampel berdasarkan 4 kemiringan lereng yaitu datar ( 0-3\%), landai (3-8\%), bergelombang (8-15\%), dan berbukit (15-30\%). Data yang diperoleh disajikan dalam bentuk diagram boxplot dan dilakukan uji korelasi antara populasi dan biomassa cacing tanah dengan sifat kimia tanah untuk mengetahui kesuburan kimia tanahnya. Hasil penelitian menunjukkan bahwa populasi cacing tanah dipengaruhi oleh vegetasi pada masing-masing kemiringan lereng dan populasi cacing tanah berkorelasi positif dengan kesuburan tanah di Laboratorium Lapang Terpadu. Uji korelasi menunjukkan bahwa populasi cacing tanah berkorelasi nyata dengan P-tersedia tanah dan kadar air tanah berpengaruh nyata terhadap populasi cacing tanah. Dari hasil identifikasi terdapat cacing tanah dari famili Glossoscolecidae yaitu genus Pontoscolex.
\end{abstract}

Kata kunci : bahan organik, cacing tanah, kemiringan lereng, vegetasi.

\section{PENDAHULUAN}

Laboratorium Lapang Terpadu Fakultas Pertanian Universitas Lampung merupakan salah satu fasilitas yang disediakan untuk menunjang kegiatan perkuliahan dengan praktek lapang dan pengembangan teori di kelas. Berbagai macam vegetasi terdapat di Laboratorium Lapangan Terpadu FP Unila. Hal ini dikarenakan setiap bagian dari lahan yang terdapat di Laboratorium Lapang Terpadu FP Unila telah dibagi sesuai dengan kebutuhan penggunaan. Namun ada pula bagian lahan yang dibiarkan dan menjadi lahan tidak terganggu.

Laboratorium Lapang Terpadu FP Unila terbagi menjadi beberapa unit lahan yang dibagi berdasarkan dengan kemiringan lerengnya. Kemiringan lereng ini dapat mempengaruhi kualitas unsur hara di dalam tanah. Berbagai penelitian melaporkan bahwa populasi dan biomassa cacing tanah pada suatu lahan dipengaruhi oleh banyak faktor, salah satunya adalah vegetasi yang tumbuh di atasnya. Vegetasi tersebut akan mempengaruhi serasah yang akan menjadi sumber energi bagi fauna tanah termasuk cacing tanah. Ketebalan serasah yang terdapat dipermukaan tanah akan mempengaruhi temperatur tanah dan kelembaban tanah dan berkaitan dengan aktivitas fauna tanah. Serasah dianggap sebagai sumber makanan yang paling baik bagi cacing tanah karena karbohidratnya relatif tinggi dan rendahnya kandungan ligno selulosenya. Cacing tanah tidak mampu makan serasah segar yang baru jatuh dari pohon. Serasah tersebut membutuhkan periode tertentu untuk lapuk atau terurai sampai cacing tanah mampu memakannya (Dewi dkk., 2006).

Keberadaan cacing tanah pada lahan yang tidak terganggu akan menjaga proses siklus hara berlangsung secara terus menerus. Lahan terganggu (lahan pertanian) pada umumnya memiliki cacing tanah yang mengalami penurunan populasi yang disebabkan oleh penurunan atau hilangnya sejumlah spesies tumbuhan, penurunan produksi serasah, perubahan sifat biologis, fisik dan kimia tanah, penurunan populasi fauna lain dan mikroorganisme tanah, dan perubahan iklim mikro ke 
arah yang kurang menguntungkan bagi pertumbuhan makhluk hidup di dalamnya (Nuril dkk., 1999). Hasil penelitian (Prijono, 2009) menunjukan bahwa sistem penggunaan lahan berpengaruh nyata terhadap kepadatan populasi cacing tanah. Berdasarkan pentingnya keberadaan cacing tanah sebagai salah satu makrofauna tanah, maka dilaksanakan penelitian yang bertujuan untuk mengetahui sebaran populasi cacing tanah pada setiap vegetasi di masing masing kemirigan lereng.dan melihat korelasi populasi cacing tanah dengan kesuburan tanah di Laboratorium Terpadu FP Unila.

\section{BAHAN DAN METODE}

Penelitian ini dilakukan di Laboratorium Lapangan Terpadu Fakultas Pertanian Universitas Lampung yang terletak pada posisi $5^{\circ} 22^{\prime} 11.38^{\prime \prime} \mathrm{LS}$ dan $105^{\circ} 14^{\prime} 25.96^{\prime \prime}$ BT sampai $5^{\circ} 21^{\prime}$ 58.35" LS dan 105' 14' 43.83" BT dengan ketinggian tempat $110-130 \mathrm{~m}$ dpl. Penelitian dilakukan pada November 2015-April 2016. Metode yang digunakan dalam penelitian ini yaitu dengan menggunakan metode survei dengan teknik purpose sampling yang titik samplingnya telah ditentukan sebelumnya. Cara perhitungan cacing tanah dengan menggunakan metode pemilihan dengan tangan (hand sorting). Data yang telah didapat dianalisis menggunakan diagaram boxplot untuk mengetahui sebarannya dan dilakukan uji korelasi antara populasi cacing tanah dengan sifat kimia tanah sehingga didapat kesimpulan yang akan mewakili hasil penelitian.

\section{HASIL DAN PEMBAHASAN}

Populasi cacing tanah pada pengambilan sampel 1 (November 2015) tidak detemukan pada semua vegetasi melainkan hanya pada vegetasi bambu pisang, singkong, dan alang-alang. Sedangkan pada pengambilan sampel 2 (Februari 2016) populasi cacing tanah ditemukan di semua vegetasi. Pada pengambilan sampel 1 (November 2015) populasi cacing tanah tertinggi tedapat pada vegetasi pisang $\left(\mathrm{P}_{2} \mathrm{~B}\right)$. Pada pengambilan sampel ke 2 (Februari 2016) populasi cacing tanah tertinggi terdapat pada vegetasi sawah (SD), terjadi peningkatan populasi cacing tanah di semua vegetasi kecuali pada vegetasi pisang $\left(\mathrm{P}_{2} \mathrm{~B}\right)$. Hal ini diduga akibat keadaan lingkungan disekitar vegetasi pisang yang selalu mendukung pertumbuhan cacing tanah. Pengambilan sampel cacing tanah dilakukan sebanyak dua kali yaitu pengambilan sampel pertama pada November 2015 dan pengambilan sampel kedua pada Februari 2016. Pada dua waktu pengambilan sampel tersebut, pengambilan sampel pertama menunjukan keadaan suhu yang lebih tinggi dan kadar air yang rendah dibandingkan dengan pengambilan sample kedua, kondisi suhu rendah dan kadar air tinggi merupakan faktor lingkungan yang medukung populasi cacing tanah. Hal ini yang menyebabkan populasi cacing tanah pada pengambilan sampel ke-2 lebih banyak dibandingkan dengan pengambilan sampel ke-1.

Populasi Cacing Tanah. Berdasarkan hasil pengamatan populasi cacing tanah pada pengambilan sampel pertama (November 2015), populasi cacing tanah tertinggi ditemukan pada kedalaman $0-10 \mathrm{~cm}$ sebanyak 64 ekor $\mathrm{m}^{-2}$ di vegetasi pisang pada kemeringan lereng 8-15\%. Hasil penelitian Maftuah (2006) menunjukkan bahwa cacing tanah menyukai daerah sekitar pertanaman pisang yang memilki kondisi lembab serta kadar air yang tinggi, hal ini sesuai dengan daerah sekitar pertanaman vegetasi pisang yang memiliki kelembaban serta kadar air yang tinggi.

Pada kedalaman 10-20 cm, populasi cacing tanah ditemukan pada vegetasi bambu dan pisang $(8-15 \%$ bergelombang). Sedangkan pada kedalaman $20-30 \mathrm{~cm}$, populasi cacing tanah ditemukan hanya pada vegetasi pisang di kemiringan lereng $(8-15 \%$ bergelombang) dengan jumlah 32 ekor $\mathrm{m}^{-2}$. Berdasarkan data tersebut maka tersaji diagram boxplot seperti pada Gambar 2. Dari diagram tersebut dapat terlihat bahwa, sebaran data terbaik terdapat pada kedalaman $0-10 \mathrm{~cm}$ dengan vegetasi singkong intensif di kemiringan lereng $8-15 \%$ (bergelombang). Hal ini ditandai dengan keseimbangan antara jumlah data yang berada di atas dan di bawah nilai tengah data, sedangkan pada vegetasi lain tidak terjadi keseimbangan tersebut sehingga diagram boxplot tidak menunjukkan proporsi yang seimbang.

Berdasarkan hasil pengamatan populasi cacing tanah pada pengambilan sampel ke-2 (Februari 2016), populasi cacing tanah tertinggi ditemukan pada kedalaman 0-10 $\mathrm{cm}$ sebanyak 128 ekor $\mathrm{m}^{-2}$ di vegetasi sawah pada kemiringan lereng 0-3\% (datar). Populasi yang tinggi pada vegetasi sawah diakibatkan pada saat pengambilan sampel kondisi lahan sawah sedang dalam keadaan tanah yang lembab namun belum tergenang, hal ini merupakan kondisi yang disukai oleh cacing tanah. Pada kedalaman 20-30 cm, populasi cacing tanah terdapat di vegetasi singkong di kemiringan lereng 3-8 $\%$ (landai) dan di vegetasi pisang, alang-alang, dan singkong intesif di kemiringan lereng 8-15\% (bergelombang).

Berdasarkan data tersebut maka tersaji diagram boxplot pada Gambar 3. Pada diagram tersebut terlihat bahwa, di pengambilan sampel ke-2 populasi cacing tanah dapat ditemukan di setiap vegetasi pada kedalaman 0-10 cm. Sebaran data terbaik terdapat pada vegetasi 
singkong intensif dengan kemiringan lereng $8-15 \%$ (bergelombang) di kedalaman 0-10 cm.

Biomassa Cacing Tanah. Berdasarkan hasil pengamatan biomassa cacing tanah pada pengambilan sampel pertama (November 2015), biomassa cacing tanah tertinggi terdapat pada vegetasi bambu di kedalaman 0-10 cm dengan kemiringan lereng $8-15 \%$ (bergelombang) sebanyak 13,6 $\mathrm{g} \mathrm{m}^{-2}$.

Berdasarkan data tersebut, maka tersaji diagram boxplot pada Gambar 4. Pada diagram tersebut dapat diketahui bahwa, tidak terdapat vegetasi yang menunjukkan sebaran data yang normal di masingmasing kedalaman. Pada kedalaman $0-10 \mathrm{~cm}$ di vegetasi bambu dan pisang, menunjukkan bahwa data yang berada di atas dari nilai tengah lebih tinggi sedangkan tidak terdapat data yang berada di bawah data nilai tengah sehingga data menyebar tidak normal.

Berdasarkan hasil pengamatan biomassa cacing tanah pada pengambilan sampel ke-2 (Februari 2016), biomassa cacing tanah tertinggi terdapat pada vegetasi alang-alang di kedalaman 0-10 cm dengan kemiringan lereng 15-30\% (berbukit) sebanyak $48 \mathrm{~g} \mathrm{~m}^{-2}$. Berdasarkan data tersebut, maka tersaji diagram boxplot pada Gambar 5. Diagram tersebut menunjukkan bahwa sebaran data terbaik terdapat pada vegetasi singkong intesif dan tebu di kemiringan lereng 8-15\% (bergelombang) kedalaman 0-10 cm. Sedangkan pada kedalaman 10-20 cm tidak ditemukan data yang menyebar normal, di vegetasi sawah ( $0-3 \%$ datar), singkong (3-8\% landai), alang-alang, singkong intensif

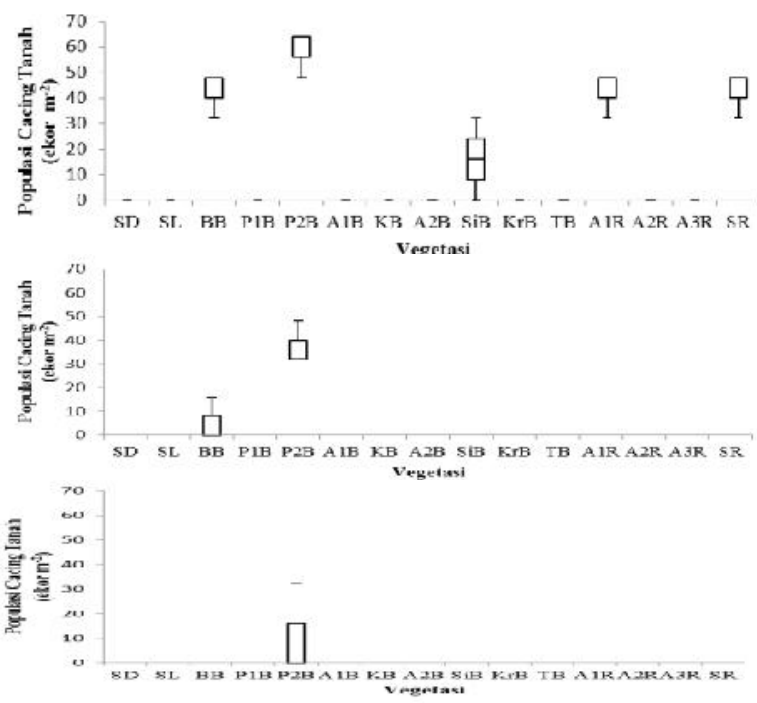

Gambar 2. Populasi cacing tanah pada pengambilan sampel ke-1 (November 2015) pada kedalaman (a) 0-10 cm, (b) 10-20 cm, dan (c) $20-30 \mathrm{~cm}$.
(8-15\% bergelombang) alang-alang dan singkong (15$30 \%$ berbukit) data yang berada di atas nilai tengah lebih banyak dibandingkan data yang berada di bawah nilai tengah dan pada vegetasi pisang (8-15\% bergelombang) data yang berada di bawah nilai tengah lebih banyak dibandingkan dengan data yang berada di atas nilai tengah sehingga diagram boxplot yang tersebut tidak menunjukkan keseimbangan proporsi dan menadakan sebaran data yang tidak normal.

Bobot Kotoran Cacing Tanah. Berdasarkan hasil pengamatan bobot kotoran cacing tanah pengambilan sampel ke-1 (November 2015) bobot kotoran cacing tanah tertinggi ditemukan pada vegetasi singkong intensif dengan jumlah $76,80 \mathrm{~g} \mathrm{~m}^{-2}$. Berdasarkan data tersebut maka tersaji diagram boxplot pada Gambar 6. Pada pengambilan sampel ke-2 (Februari 2016) bobot kotoran cacing tanah tertinggi adalah 70,72 $\mathrm{g} \mathrm{m}^{-2}$, di vegetasi bambu (kemiringan lereng $8-15 \%$ bergelombang). Berdasarkan data tersebut maka tersaji diagram boxplot pada Gambar 7.

Biomassa Serasah. Pada pengambilan sampel ke-1(November 2015) biomassa serasah ditemukan pada setiap vegetasi dengan jumlah tertinggi yaitu pada vegetasi bambu (bergelombang 8-15\%) dengan jumlah $477,30 \mathrm{~g} \mathrm{~m}^{-2}$. Berdasarkan data tersebut maka tersaji diagram boxplot pada Gambar 8. Pada pengambilan sampel ke-2 (Februari 2016) biomassa serasah tertinggi adalah $422,70 \mathrm{~g} \mathrm{~m}^{-2}$, di vegetasi tebu (bergelombang 8$15 \%)$. Berdasarkan data tersebut maka tersaji diagram boxplot pada Gambar 9.

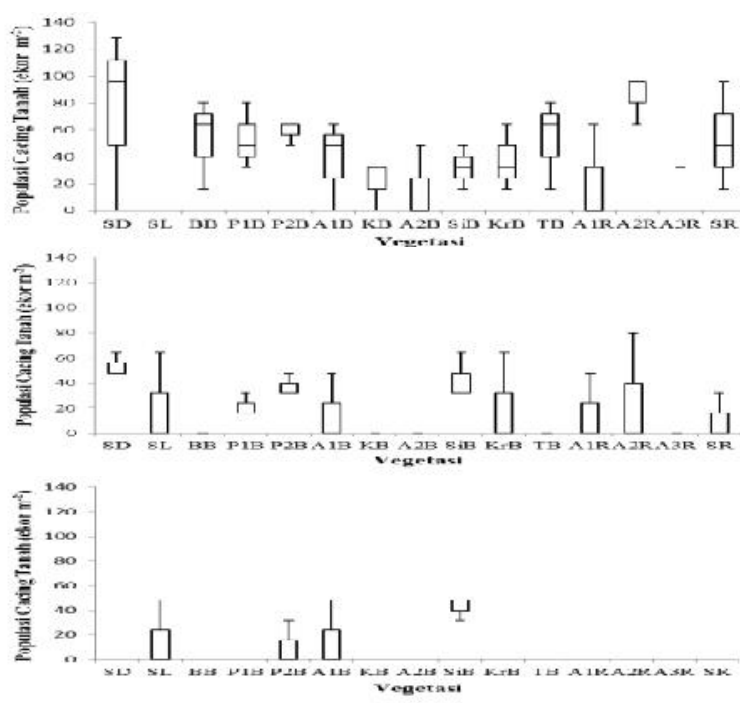

Gambar 3. Populasi cacing tanah pada pengambilan sampel ke-2 (Februari 2016) pada kedalaman (a) 0-10 cm, (b) $10-20 \mathrm{~cm}$, dan (c) $20-30 \mathrm{~cm}$. 

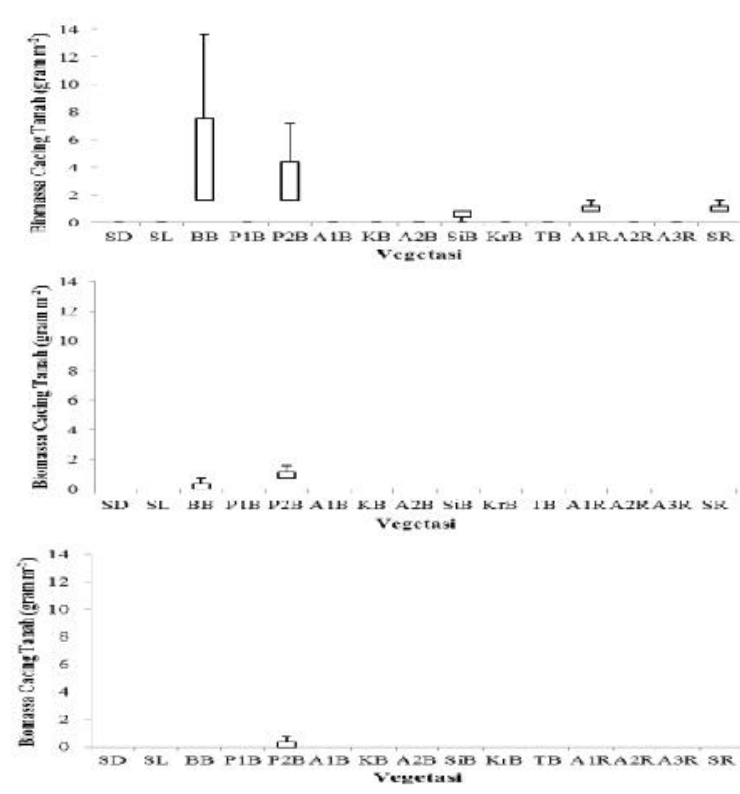

Gambar 4. Biomassa cacing tanah pada pengambilan sampel ke-1 (November 2015) pada kedalaman (a) 0-10 cm, (b) 10-20 cm, dan (c) $20-30 \mathrm{~cm}$.

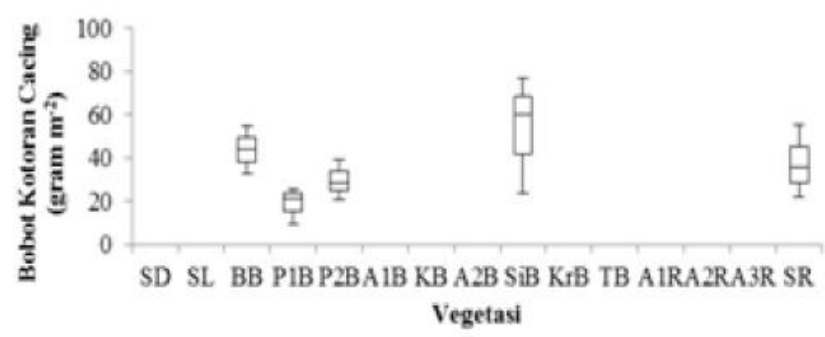

Gambar 6. Bobot kotoran cacing tanah pada pengambilan sampel ke-1 (November 2015)

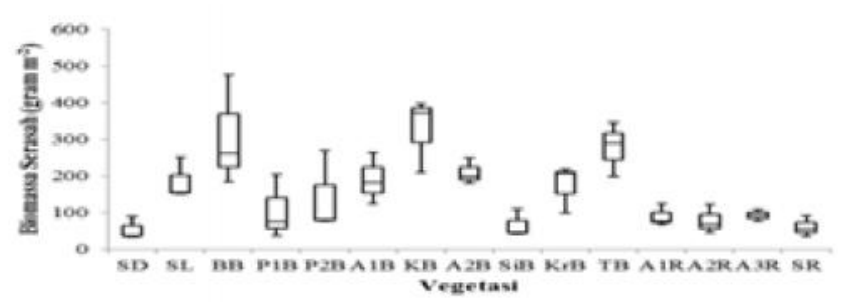

Gambar 8. Biomassa serasah pada pengambilan sampel ke-1 (November 2015)

Jenis Cacing Tanah. Berdasarkan identifikasi cacing tanah dapat diketahui bahwa jenis cacing tanah yang ada di lahan Laboratorium Lapang Terpadu FP Universitas Lampung tersebut merupakan famili Glossoscolecidae yaitu genus Pontoscolex. Cacing tanah genus Pontoscolex merupakan cacing tanah yang dicirikan dengan adanya klitelum pada segmen 14-20 dan setae berpola lumbrisin (berpasangan erat). Cacing
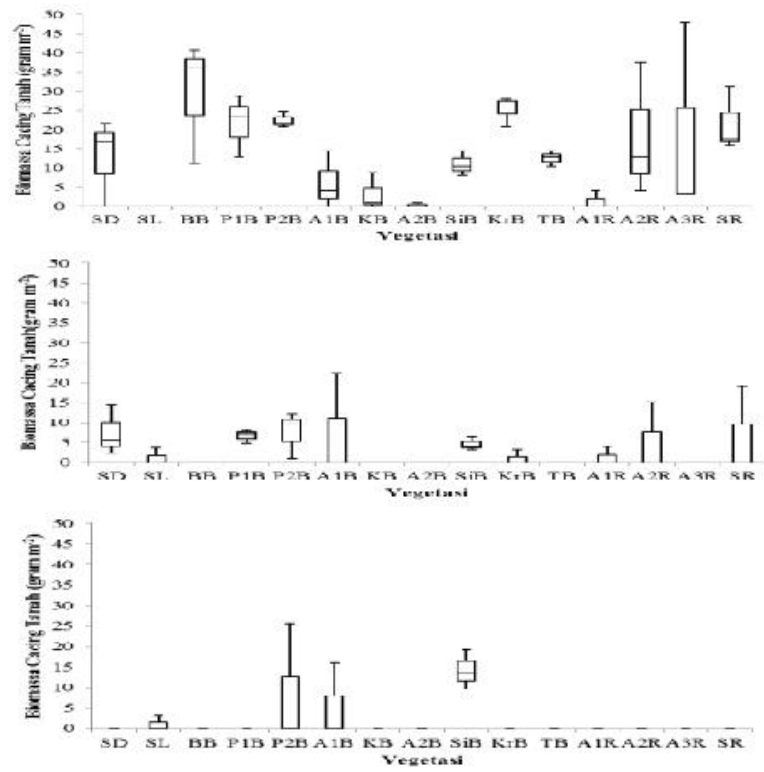

Gambar 5. Biomassa cacing tanah pada pengambilan sampel ke-2 (Februari 2016) pada kedalaman (a) 0-10 cm, (b) 10-20 cm, dan (c) $20-30 \mathrm{~cm}$.

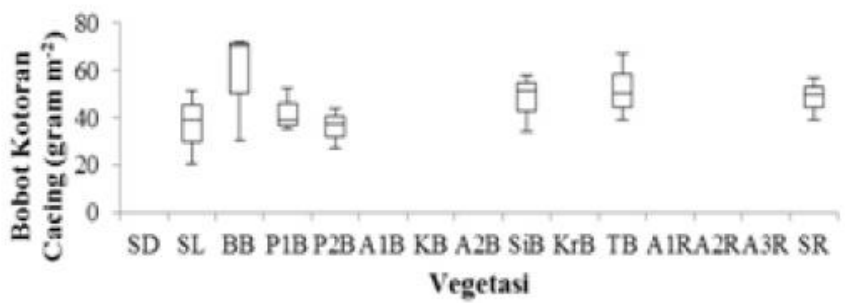

Gambar 7. Bobot kotoran cacing tanah pada pengambilan sampel ke-2 (Februari 2016)

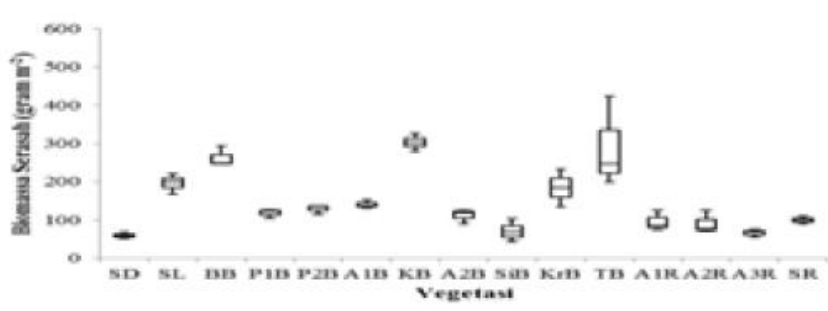

Gambar 9. Biomassa serasah pada pengambilan sampel ke-2 (Februari 2016)

tanah pada pengamatan kali ini memiliki klitelum pada segmen ke-14 (Gambar 10.A) dan memiliki pola setae lumbrisin (Gambar 10.B).

Jenis cacing tanah yang ditemukan merupakan cacing tanah yang aktif dipermukaan, rata-rata memiliki ukuran yang besar, banyak terdapat pada kedalaman 0 $10 \mathrm{~cm}$, dibandingkan pada kedalaman $10-20 \mathrm{~cm}$ maupun 20-30 cm sehingga dapat dikatakan bahwa cacing tanah 

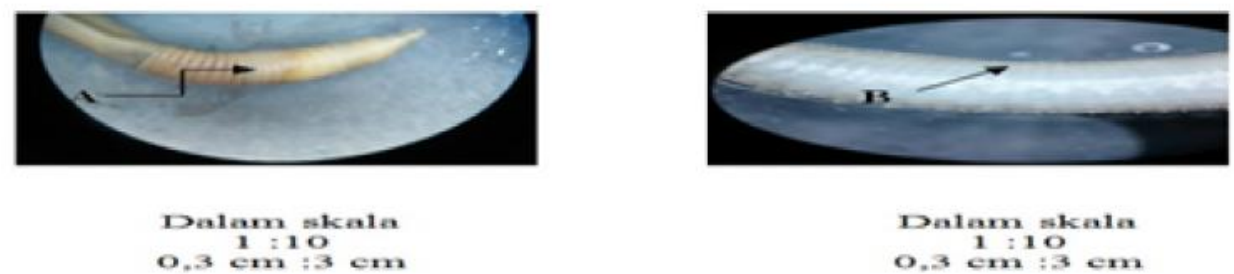

Gambar 10. Identifikasi cacing tanah hasil pengamatan A. Klitelum Pontoscolex B. Setae lumbrisin

pada lahan di laboratorium lapang terpadu termasuk kelompok cacing tanah epigaesis. Cacing tanah epigaesis merupakan cacing yang aktif dipermukaan, warna gelap, penyamaran efektif, tidak membuat lubang, pemakan serasah dipermukaan (Edwards,1998).

Hubungan antara Populasi dan Biomassa Cacing Tanah dengan Beberapa Sifat Kimia Tanah. Hasil uji korelasi pada Tabel 4 menunjukkan populasi, biomassa, dan bobot kotoran cacing tanah tidak berkorelasi nyata dengan N-total, P-tersedia dan K-dd tanah di pengambilan sampel ke-1 (November 2015) sedangkan pengambilan sampel kedua (Februari 2016) populasi cacing tanah berkorelasi nyata dengan Ptersedia tanah. Cacing tanah mengeluarkan hasil metabolisme berupa kotoran cacing tanah (kascing), kotoran cacing tanah memiliki kandungan unsur hara seperti $\mathrm{N}, \mathrm{P}, \mathrm{K}, \mathrm{Ca}, \mathrm{Mg}, \mathrm{S}$ dan unsur lainnya yang dibutuhkan oleh tanaman. Kotoran cacing tanah mengandung $\mathrm{P}$-tersedia dalam jumlah yang besar yaitu $150 \mathrm{ppm}$ sehingga dapat meningkatkan jumlah P-tersedia yang terdapat didalam tanah dengan populasi cacing tanah yang tinggi.

Hasil uji korelasi pada Tabel 5 menunjukkan pada pengambilan sampel kedua (Februari 2016) kadar air tanah tanah berkorelasi nyata dengan populasi cacing tanah. Cacing tanah sangat sensitif dengan kadar air tanah, karena kadar air tanah akan mempengaruhi kelembaban tanah yang sangat dibutuhkan oleh cacing tanah untuk menjaga kulitnya agar dapat berfungsi normal yaitu untuk berespirasi. Berat tubuh cacing tanah terdiri dari $75-90 \%$ air, sehingga kelembaban tempat hidupnya sangat penting.

\section{KESIMPULAN}

Dari hasil penelitian dapat disimpulkan bahwa populasi cacing tanah yang terdapat di Laboratorium Lapang Terpadu Unila dipengaruhi oleh vegetasi pada setiap kemiringan lereng yang berbeda, populasi cacing tanah tertinggi pada pengambilan sampel 1 (November 2015) terdapat pada vegetasi pisang 64 ekor $\mathrm{m}^{-2}$ (bergelombang 8-15\%) dan populasi cacing tanah tertinggi pada pengambilan sampel ke 2 (Februari 2016) terdapat pada vegetasi sawah yaitu $128 \mathrm{ekor} \mathrm{m}^{-2}$ (datar 0-3\%). Biomassa cacing tanah tertinggi pada pengambilan sampel 1 (November 2015) adalah 13,6 g $\mathrm{m}^{-2}$ dan biomassa cacing tertingi pada pengambilan sampel ke 2(Februari 2016) adalah $48 \mathrm{~g} \mathrm{~m}^{-2}$. Populasi cacing tanah yang tinggi mengakibatkan jumlah Ptersedia tanah meningkat sesuai dengan uji korelasi populasi cacing tanah dengan sifat kimia tanah yaitu Ptersedia tanah yang menunjukan korelasi yang nyata sedangkan biomassa cacing tanah tidak berkorelasi nyata dengan sifat kimia tanah di Laboratorium Lapang Terpadu Unila. Cacing tanah yang ditemukan di Laboratorium Lapang Terpadu pada berbagai vegetasi di masing-masing kemiringan lereng adalah cacing tanah dari famili Glossoscolecidae yaitu genus Pontoscolex.

\section{DAFTAR PUSTAKA}

Banuwa, I.S., 2014. Bahan Praktikum Lapang Laboratorium Lapang Terpadu. Universitas Lampung. Bandar Lampung. $12 \mathrm{hlm}$.

Budiarti, A. dan R. Palungkun. 1992. Cacing Tanah : Aneka Cara Budidaya, Penanganan Lepas Panen, Peluang Campuran Ransum Ternak dan Ikan. Penebar Swadaya. Jakarta.48 hlm

Dewi, W.S. 2001. Biodiversitas Tanah pada Berbagai Sistem Penggunaan Lahan. Jurnal Ilmiah Lingkungan Hidup, 1(2) : 16-21.

Dewi, W. S., B. Yanuwiyadi, D. Suprayogo, dan K. Hairiah.2006. Alih guna hutan menjadi lahan pertanian: (1) Dapatkah sistem agroforestri kopi mempertahankan diversitas cacing tanah di Sumberjaya. Jurnal Agrivita, 28 (03): 27-54.

Edwards, C.A. 1998. Earthworm Ecology. St. Lucie Press. Washington, DC. $365 \mathrm{hlm}$.

Maftu'ah, E., E. Ariesoesilaningsih, dan E. Handayanto. 2006. Studi Potensi Diversitas Makrofauna Tanah Sebagai Bioindikator Kualitas Tanah pada 
Beberapa Penggunaan Lahan. J. Biosains, 2 (2) :34-47.

Nuril, H., B. P. Naiola, E. Sambas, F. Syarif, M. Sudiana, J. S. Rahajoe, Suciatmih, T. Juhaeti, dan Y. Suhardjono. 1999. Perubahan Bioekofisik Lahan Bekas Penambangan Emas di Jampang dan Metoda Pendekatannya untuk upaya reklamasi. Laporan Teknik Proyek Penelitian Pengembangan dan Pendayagunaan Potensi Wilayah, Tahun 1998/1999. Puslitbang Biologi LIPI. 25 hlm.

Prijono, S. dan H. A. Wahyudi. 2009. Peran Agroforestry Dalam Mempertahankan Makroporisitas Tanah. Jurnal Primordia, 5 (03): 201-212.
Rahmawaty. 2004. Studi Keanekaragaman Mesofauna Tanah Di Kawasan Hutan Wisata Alam Sibolangit (Desa Sibolangit, Kecamatan Sibolangit, Kabupaten Daerah Tingkat II Deli Serdang, Propinsi Sumatera Utara). Skripsi. Universitas Sumatera Utara. Medan. $78 \mathrm{hlm}$.

Sugiarto, Y. 2003. Konservasi Makrofauna Tanah dalam Sistem Agroforestri. Puslitbang Bioteknologi dan Biodiversitas LPPM UNS. Surakarta. 